\title{
ORBITAL VOLUME ASSESSMENT ACCORDING TO MSCT DATA IN PATIENTS WITH MIDFACE TRAUMA
}

\author{
Pavlova O. Yu. 1, Serova N.S. ', Davydov D.V.2, Peric B. ${ }^{3}$
}

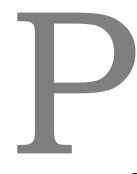

urpose. To acquire additional diagnostic information in patients with orbital trau- 1 - Sechenov University. ma in order to identify the risk of postoperative enophthalmos. To evaluate the ad- 2 - Peoples Friendship vantages of MSCT data postprocessing and volume orbital measurement. University of Russia.

Materials and methods. A total of 71 patients (100\%) with midface trauma were Moscow, Russia. studied in Sechenov University using pre- and postoperative volume 640-slice CT. Post pro- 3 - Falu Lasarett. cessing of MSCT data included workstation special software, where the bone borders of the Falun, Sweden. orbits before and after surgical treatment were marked on every slice and presented in mathematical units (ml).

Results. Preoperative MSCT revealed increased orbital volume in 64 patients $(90 \%)$ due to severe midface trauma, the difference between traumatized and normal orbit was from $2 \mathrm{ml}$ to $14 \mathrm{ml}$, these patients required surgical treatment. The other 7 patients $(10 \%)$ had mild midface trauma, the difference between orbital volumes was less than $2 \mathrm{ml}$, these patients didn't undergo surgical treatment.

After the operation in 55 patients $(77 \%)$ the orbital volume was reconstructed - the difference between orbital volumes was not more than $2 \mathrm{ml}$. In 9 cases $(13 \%)$ orbital volume difference was more than $2 \mathrm{ml}$ which means that these patients still had risk of postoperative enophthalmos and required additional diagnostic control and potential surgical correction.

Conclusion. Postprocessing of the MSCT data gave the possibility to calculate preand postoperative orbital volume changes and present it in mathematical units $(\mathrm{ml})$ in $3 \mathrm{D}$ mode. As the result the additional information can be acquired in order to identify the risk of postoperative enophthalmos.

Keywords: MSCT, data postprocessing, enophthalmos, volume orbital.

Corresponding author: Pavlova O. Yu., e-mail: dr.olgapavlova@gmail.com

For citation: Pavlova O. Yu., Serova N.S., Davydov D.V., Peric B. Orbital volume assessment according to msct data in patients with midface trauma. REJR 2018; 8 (1):29-39. DOI:10.21569/2222-7415-2018-8-1-29-39.

Received: $\quad 10.03 .2018 \quad$ Accepted: 23.03 .2018

\section{МЕТОАИКА ОЦЕНКИ ОБЪЁМОВ ОРБИТ ПО ААННЫМ МСКТ У ПАЦИЕНТОВ С ТРАВМОЙ СРЕАНЕЙ ЗОНЫ АИЦА}

\author{
Пав^ова О.Ю. 1, Серова Н.С. ${ }^{1}$, АавыАов А.В.2, Перич Б.3
}

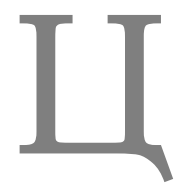

ель исследования. Разработать методику измерения объёмов орбит у пациентов с травмой средней зоны мица на до- и послеоперационном этапах $е$ чения на основе данных МСКТ. Изучить возможности измерения объёмов орбиты с целью получения дополнительной диагностической информации дмя оценки риска развития энофтальма.

Материалы и методы. В клинике Сеченовского Университета был обследован 71 пациент (100\%) с травмой орбиты. На до- и послеоперационном этапах обследования всем пациентам ( $\mathrm{n}=71,100 \%)$ была выполнена мультиспиральная компьютерная томография на аппарате Toshiba Aquilion One 640, с толщиной среза 0,5 мм, в костном и мягкотканном режимах. Для измерения объёмов орбиты обработка МСКТ данных проводилась на рабочей станции Vitrea и включала в себя маркировку костных

1 - Сеченовский Университет. 2 - Российский университет дружбы народов.

г. Москва, Россия.

3 - Фалу Аазарет.

г. Фалун, Швеция. 
границ правой и мевой орбиты до и после хирургического мечения на каждом аксиальном срезе с представцением объёмов орбит в мц.

Результаты. Обработка MCKT данных на предоперационном этапе показала увеличение объёма травмированной орбиты у 64 пациентов (90\%), размичия объёмов

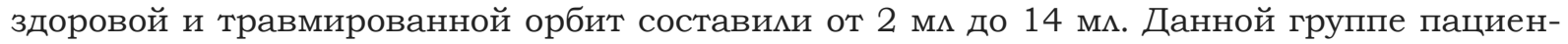
тов бымо проведено реконструктивное хирургическое мечение. У 7 пациентов (10\%) с травмами средней зоны мица мегкой степени тяжести разцичия в объёмах орбиты не превышало 2 м^, что является положительным прогностическим фактором, данные пациенты получали консервативное мечение.

После хирургического мечения у 55 пациентов (77\%) объём травмированной орбиты восстановицся, разница объёмов здоровой и травмированной орбит составица менее 2 мл. В 9 случаях (13\%) разница объёмов здоровой и травмированной орбит составила более 2 мл, что явцяется неблагоприятным прогностическим фактором и говорит о сохраняющемся риске развития энофтальма. У пациентов данной группы необходимо проведение дополнительного диагностического обследования в раннем и позднем послеоперационном периодах.

Выводы. Разработанная методика обработки MCKT данных дает возможность определять изменения объёмов здоровой и травмированной орбит на до- и послеоперационных этапах мечения. В результате методика оценки объёмов орбит даёт возможность получения дополнительной диагностической информации для оценки риска развития энофтальма.

Ключевые слова: МСКТ, обработка данных, энофтальм, объём орбиты.

Контактный автор: Павцова О.Ю., e-mail: dr.olgapavlova@gmail.com

Для ијитирования: Павлова О.Ю., Серова Н.С., Давыдов Д.В., Перич Б. Методика оиенки объёмов орбит по данньм мскт у паииентов с травмой средней зоны лииа. REJR 2018; 8 (1):29-39. DOI:10.21569/2222-7415-2018-8-1-29-39.
Статья получена:
10.03.2018
Статья принята:
23.03.2018

$\mathrm{N}$ owadays the problem of midface and orbital trauma retains its high relevance and significance as it is constantly recorded growing rates of facial trauma [1, $4,6,7,8,11,13,14,17,22,24]$. Orbital trauma often results in persistent both aesthetic and functional impairment including complete or partial vision loss, different injury of oculomotor muscles system, deformation of paranasal sinuses and airways [1-5, 11, 15, 18, 23]. One of the most typical and important clinical features is a multiply injury which includes bone and soft tissues and brain trauma. Besides, both type and character of the trauma have become more severe and complicated and could lead to patients' disability $[1-4,9,12,19,25]$. According to the WHO data, incidence of orbital trauma is increasing world widely every year due to the urban growth, developing mechanization and various substance abuse Males of the working age are the most exposed group with average disability rate about $23,5 \%[1,2,4,6,8,10,16,20]$.
Therefore the role of proper pre- and postoperative diagnostics using multislice computed tomography (MSCT) in such injuries is very important and can hardly be overestimated $[3,4,5$, $6,7,10,21]$.

However, it is not enough to only perform correct and well-timed diagnostic modality to establish the fact of orbital trauma. Nowadays toppriority aim in diagnostic procedures in patients with orbital trauma is development of special postprocessing of the MSCT data to acquire additional diagnostic information in order to establish the effective patient's management [3, 4, 20-25].

\section{Purpose.}

To acquire additional diagnostic information in patients with orbital trauma in order to identify the risk of postoperative enophthalmos. To evaluate the advantages of MSCT data postprocessing and volume orbital measurement.

Material and methods.

A total of 71 patients $(100 \%)$ with midface trauma were studied in Sechenov University using 
pre- and postoperative volume 640-slice CT (Toshiba Aquilion One 640).

Scanning parameters: area of interest - facial skeleton, scanning mode - volume, slice thickness $-0,5 \mathrm{~mm}$, field of view $-16 \mathrm{sm}$, voltage -100 $\mathrm{kV}$, current intensity - $60 \mathrm{~mA}$, time of scanning 1-2 sec, reconstruction type - bone. A patient is lying on the back during the study, the patient's head is fixed on the headrest.

For measurement of orbital volumes post processing of MSCT data included workstation special software, where the bone borders of the orbits before and after surgical treatment were marked on every slice and presented in mathematical units (ml).

According to the developed method of orbital volumes calculating, a patent was obtained RU (11) 2638623 (13) C1, 14.12.2017 Bul. № 35.

The method of orbital volume's measurement:

1. Definition of the bone orbital borders, where the marking will take place, were performed. The necessity for the correct study implementation is the symmetry of the bone borders for both orbits. To determine the external marking border, it is necessary to draw a line through the entire length of the orbit and to build perpendicular to its length, performed for both orbits at once (Fig. 1).

2. On every axial slice the orbital bone borders were marked from the superior orbital wall to the level of orbital floor (Fig. 2). For the measurements accuracy, it is necessary to strictly observe the bone borders and take into account the anatomical variations of orbital walls, as well as the areas of damage orbital walls.

3. After the orbital volume measurement acquired results compared before and after the reconstructive surgery (Fig. 3).

\section{Results.}

Preoperative MSCT revealed increased orbital volume in 64 patients $(90 \%)$ due to severe midface trauma, the difference between traumatized and normal orbit was from $2 \mathrm{ml}$ to $14 \mathrm{ml}$.

These patients required surgical treatment, because it is believed that with a difference in orbital volumes more than $2 \mathrm{ml}$, globe displacement increases by $1 \mathrm{~mm}$ and, as a result, the risk of enophthalmos increases, which is a reliable prognostic factor and can be used for planning and evaluation of the surgical treatment effectiveness.

The other 7 patients (10\%) had mild midface trauma, the difference between orbital volumes was less than $2 \mathrm{ml}$, which is a positive prognostic factor, these patients didn't undergo surgical treatment.

After the operation in 55 patients (77\%) the orbital volume was reconstructed - the difference between orbital volumes was not more than $2 \mathrm{ml}$. In 9 cases $(13 \%)$ orbital volume difference was more than $2 \mathrm{ml}$ which means that these patients still had risk of postoperative enophthalmos. These patients require additional diagnostic control and potential surgical correction with performance of control MSCT for dynamic in the early and late postoperative periods.

\section{Clinical case.}

A male patient, 59 y.o., was admitted to the Sechenov University within 48 hours after face trauma (fall from height, 2nd floor).

During the clinical examination, changed facial configuration and increased right paraorbital area due to soft tissue edema was determined, as well as skin abrasions, hematomas in the upper and lower eyelids, narrowing of the right ocular gap, numbness of the infraorbital region. Vision or globe movement impairment was not revealed.

MSCT was performed using Toshiba Aquilion One 640 scanner, volume mode, slice thickness $0,5 \mathrm{~mm}$, bone and soft tissue reconstruction. For postprocessing of MSCT data workstation "Vitrea" was used.

MSCT revealed fracture of the right orbital floor and lateral wall, anterior and lateral maxillary sinus walls and fractures of zygomatic arch, there was no herniation of orbital content into the maxillary sinus (Fig. 4). The fracture localized in the lateral and central area of orbital floor.

According to the MSCT "raw" data, it was not possible to estimate the change in the right orbit volume for comparison with the contralateral side. For this purpose, a special technique was used to process CT images, calculate the volumes of both orbits and present them in $\mathrm{ml}$ for a detailed assessment of orbital post-traumatic changes.

For the postprocessing of MSCT data definition of the bone orbital borders, where the marking will take place, were performed. The necessity for the correct study implementation is the symmetry of the bone borders for both orbits. To determine the external marking border, it is necessary to draw a line through the entire length of the orbit and to build perpendicular to its length, performed for both orbits at once. On every axial slice the orbital bone borders were marked from the superior orbital wall to the level of orbital floor. For the measurements accuracy, it is necessary to strictly observe the bone borders and take into account the anatomical variations of orbital walls, as well as the areas of damage orbital walls

The difference between the affected and normal orbits according to the orbital volume assessment was $0,4 \mathrm{ml}$ (Fig. 5). According to the literature data it is believed that with a difference in orbital volumes more than $2 \mathrm{ml}$, globe displace- 


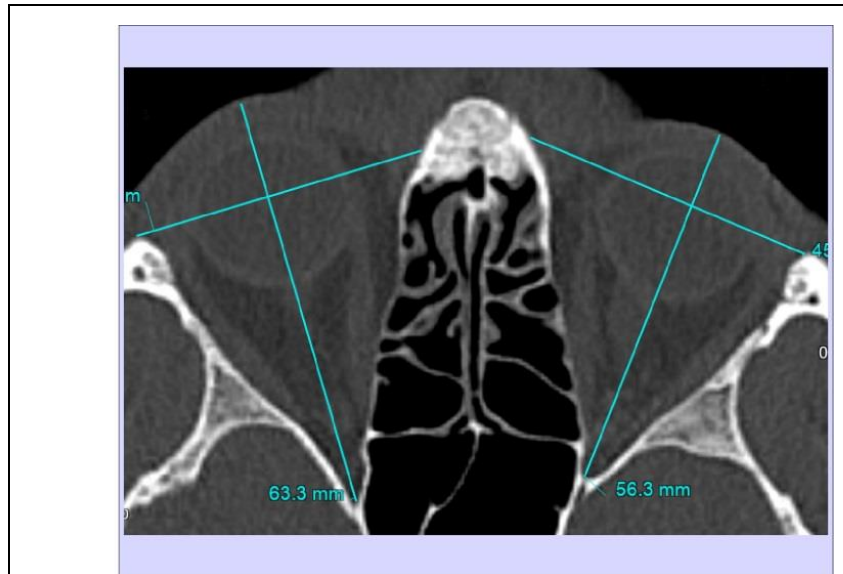

Puc. 1 a (Fig. 1 a)

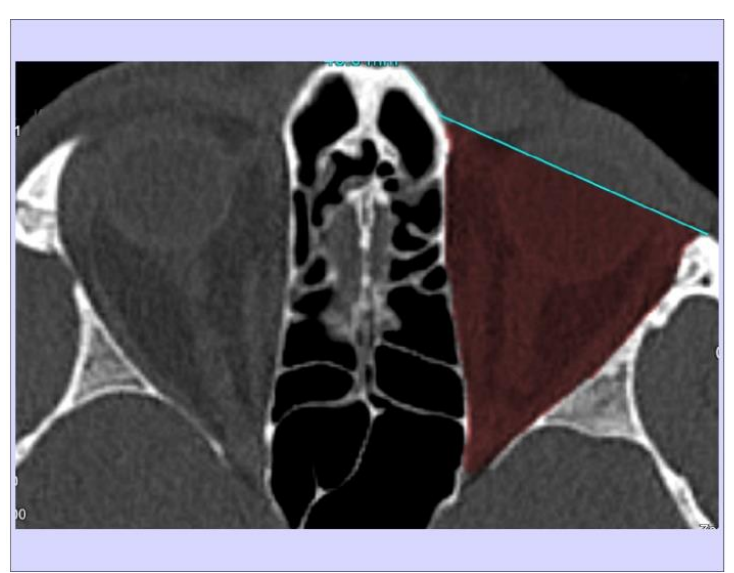

Pис. 16 (Fig. 1 в)

Fig. 1. MSCT, midface, bone window, axial reconstruction (A, B).

Definition of external orbital borders.

Рис. 1. МСКТ, среАняя зона лица, костный режим, аксиальная реконструкция (А, Б).

Опредемение наружных границ обит.

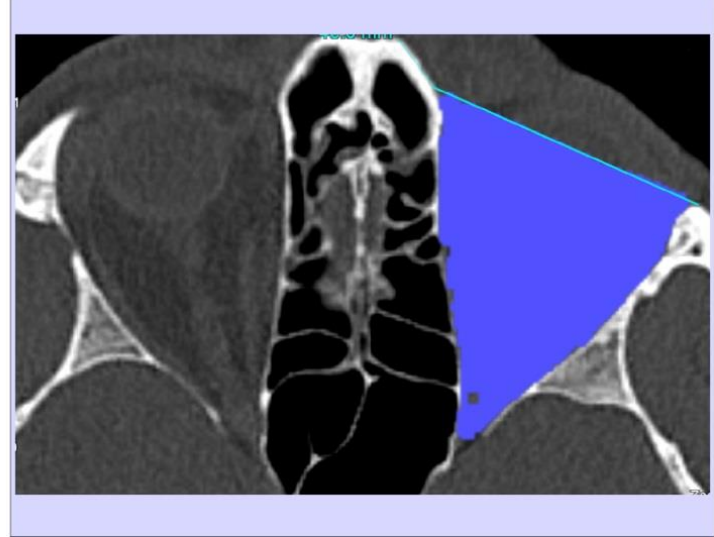

Puc. 2 a (Fig. 2 a)

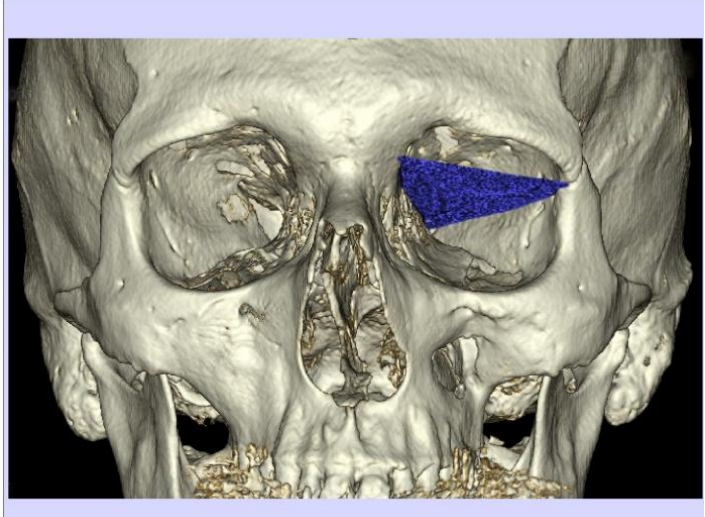

Pис. 2 б (Fig. 2 в)

Fig. 2. MSCT, midface, bone window, axial (A) and 3D (B) reconstruction.

Orbital bone borders were marked on every axial slice.

Рис. 2. МСКТ, среАняя зона Аица, костный режим, аксиальная (А) и ЗD реконструкции (Б).

Маркировка костных границ орбиты.

ment increases by $1 \mathrm{~mm}$ and, as a result, the risk of enophthalmos increases, which is a reliable prognostic factor and can be used for planning and evaluation of the surgical treatment effectiveness. Thus, in this patient the risk of developing post-traumatic enophthalmos is minimal. Considering the absence of visual impairment and orbital bony and soft tissues complications, this patient underwent conservative therapy and diagnostic control in the post-traumatic period.

As part of a dynamic control, MSCT was performed 2 years after the injury. The obtained images showed restoration of the right orbit bone walls, as well as restoration of the right maxillary sinus walls and zygomatic arch, while the deformation of the lateral sinus wall was revealed (Fig.
6). There was no herniation of orbital content into the maxillary sinus.

According to the MSCT "raw" data, it was not possible to estimate the change in the right orbit volume for comparison with the contralateral side in late posttraumatic period. For this purpose, a special technique was used to process CT images, calculate the volumes of both orbits and present them in $\mathrm{ml}$ for a detailed assessment of orbital post-traumatic changes (Fig. 7).

The difference between the affected and normal orbits in the late posttraumatic period was 0,67 $\mathrm{ml}$ which was a good prognostic factor and showed minimal risk of posttraumatic enophthalmos development.

Conclusion. 


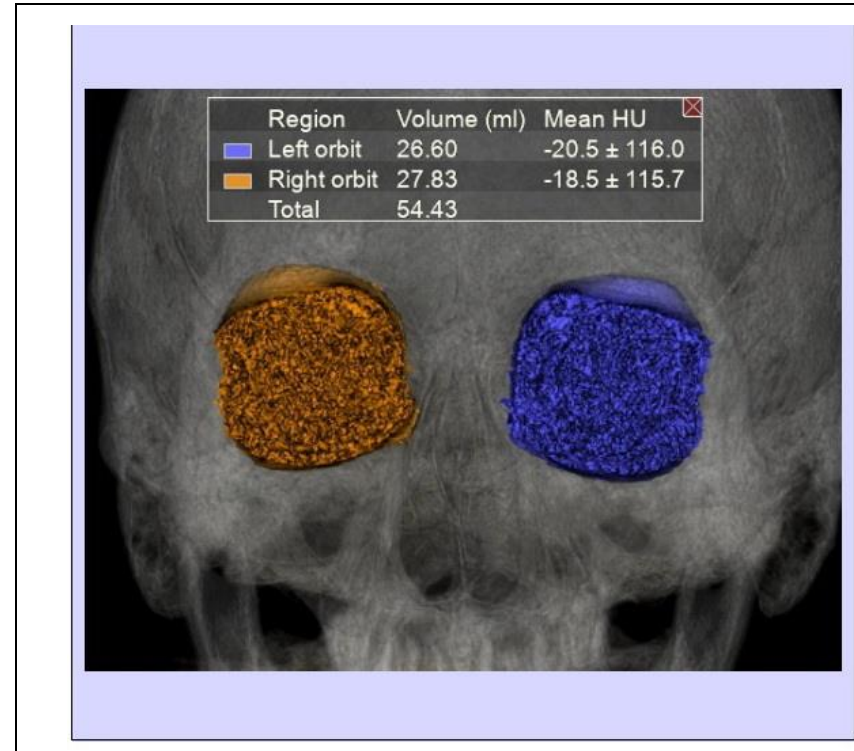

Рис. 3 a (Fig. 3 a)

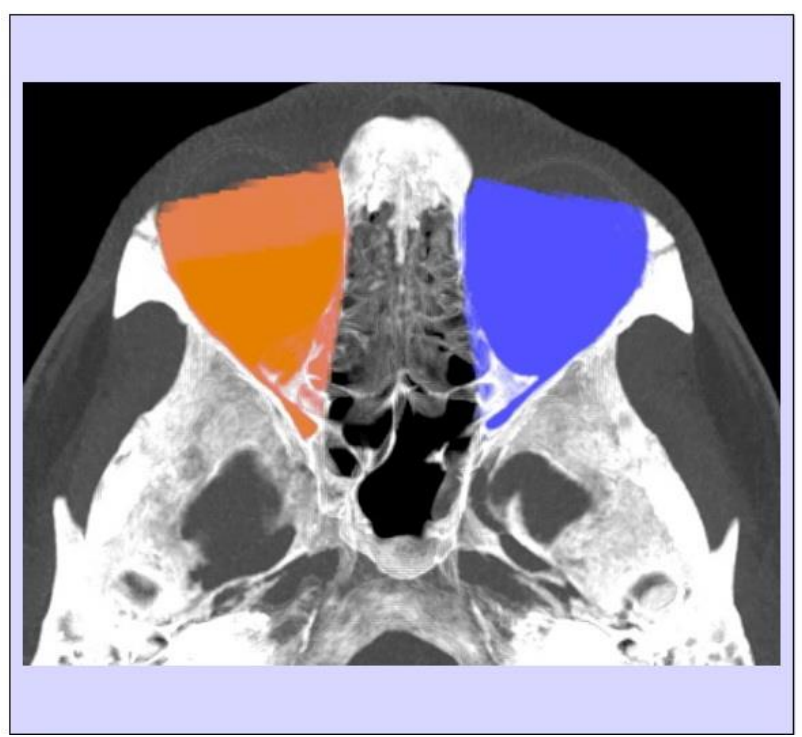

Pис. 3 в (Fig. 3 c)

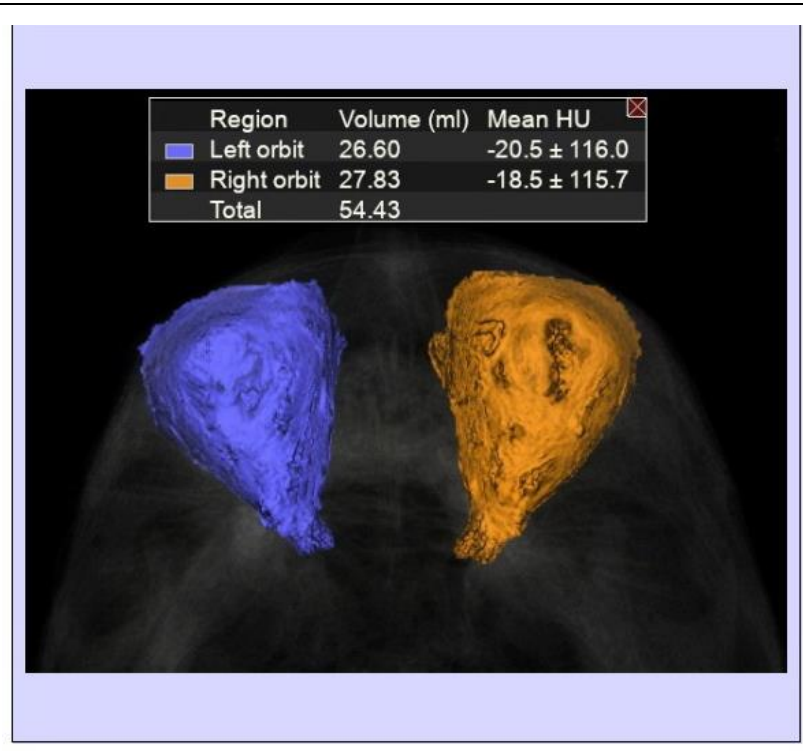

Pис. 36 (Fig. 3 в)

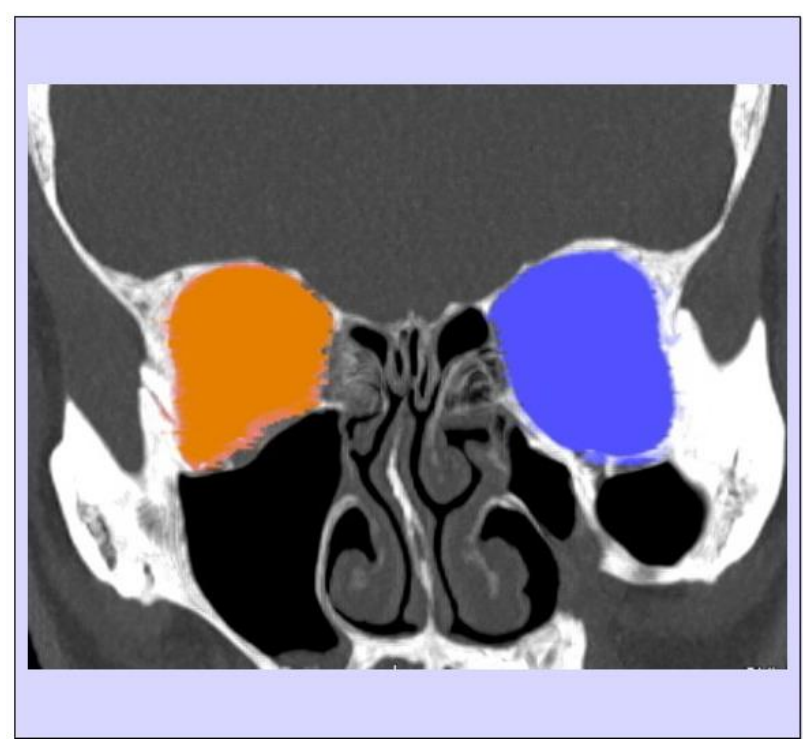

Puc. 3 r (Fig. 3 d)

Fig. 3. MSCT, midface, bone window, 3D (A), axial (B, C) and coronal (D) reconstruction.

Comparison of orbital volumes.

Рис. 3. МСКТ, среАняя зона Аица, костный режим, 3D реконструкция (А), аксиальная (Б, В) и корональная (Г) реконструкции.

Сравнение значений объемов обеих орбит. 


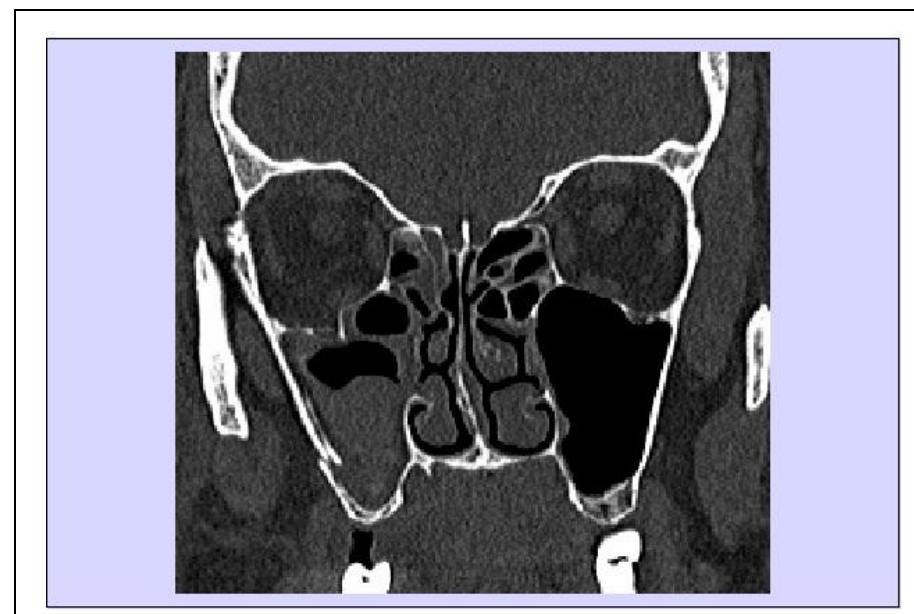

Рис. 4 a (Fig. 4 a)

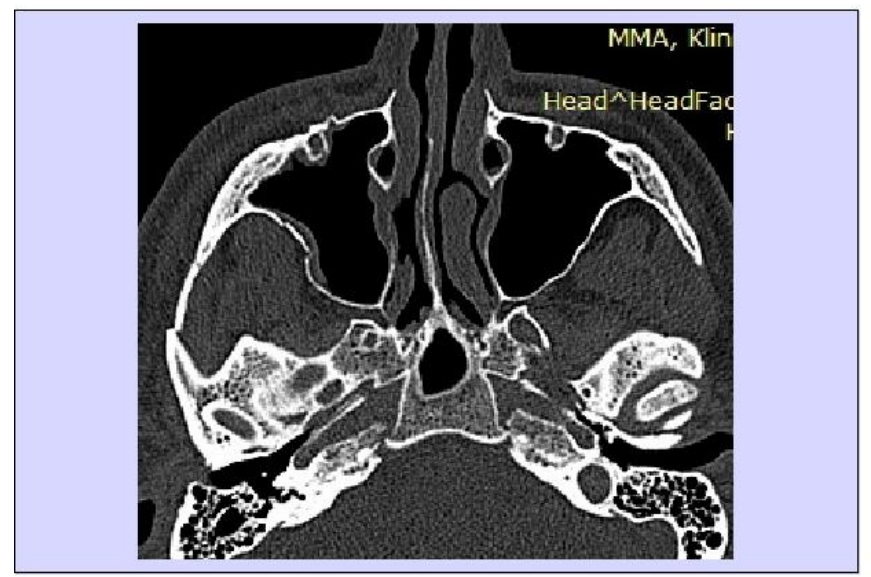

Puc. 4 в (Fig. 4 c)

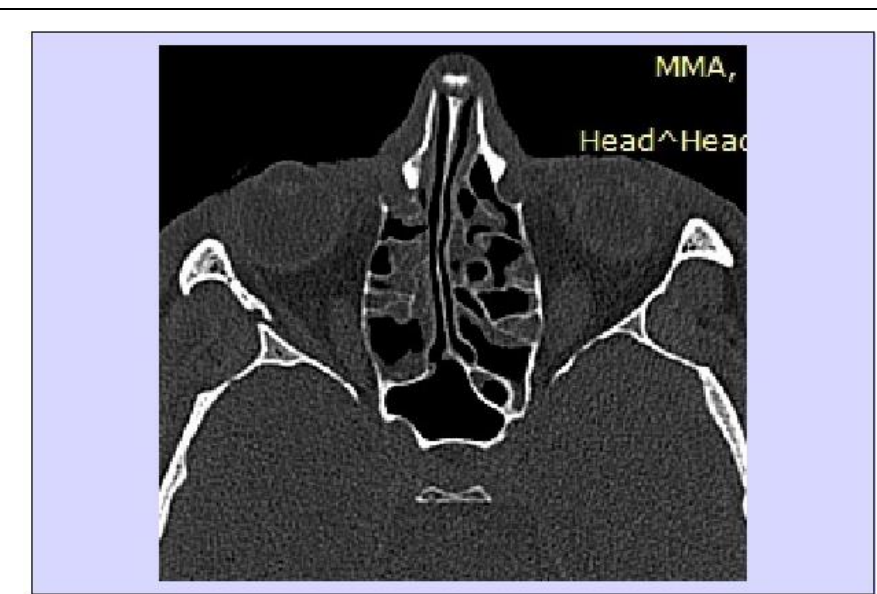

Pис. 4 б (Fig. 4 в)

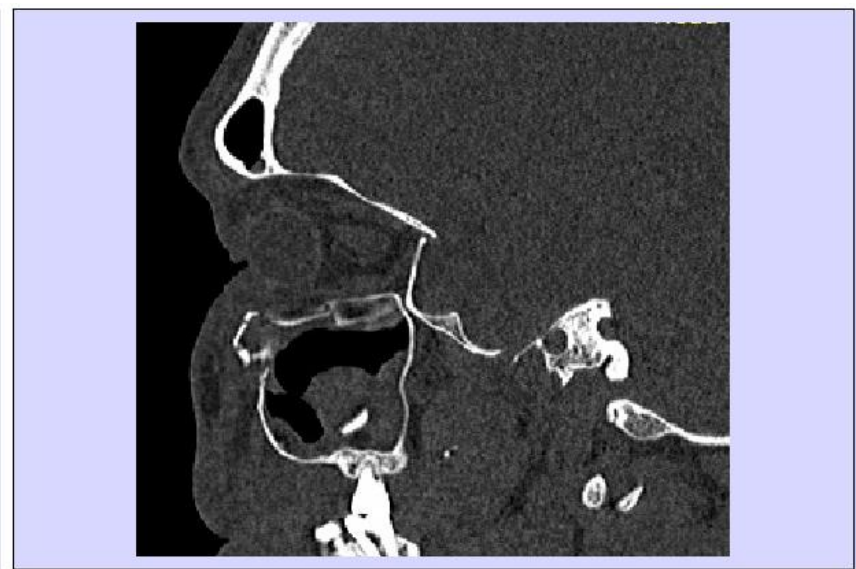

Рис. 4 г (Fig. 4 d)

Fig. 4. MSCT, midface, bone window, coronal (a), axial (b, $c)$ and sagittal (d) reconstruction.

MSCT revealed fracture of the right orbital floor and lateral wall, anterior and lateral maxillary sinus walls and fractures of zygomatic arch, there was no herniation of orbital content into the maxillary sinus.

Рис. 4. МСКТ, среАняя зона Аица, костный режим, корональная (а), аксиальная $(б$, в) и сагиттальная (г) реконструкции.

Травматические повреждения мицевого скелета справа: перелом матеральной и нижней стенок правой орбиты, перелом цатеральной и передней стенки правого верхнечелюстного синуса в области скуло-верхнечелюстного шва и двойной перелом правой скуловой дуги. 


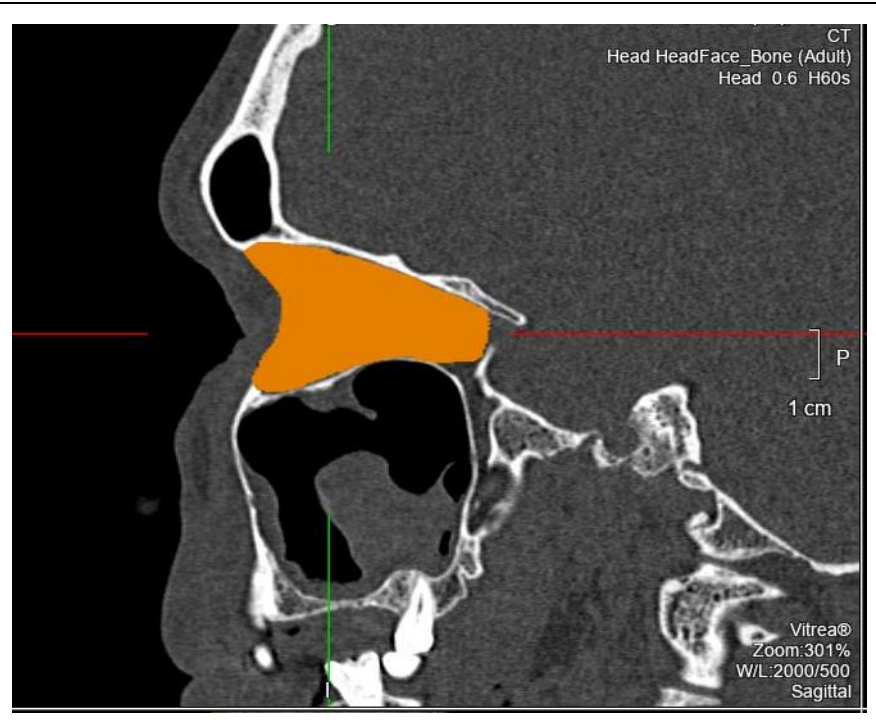

Puc. 5 a (Fig. 5 a)

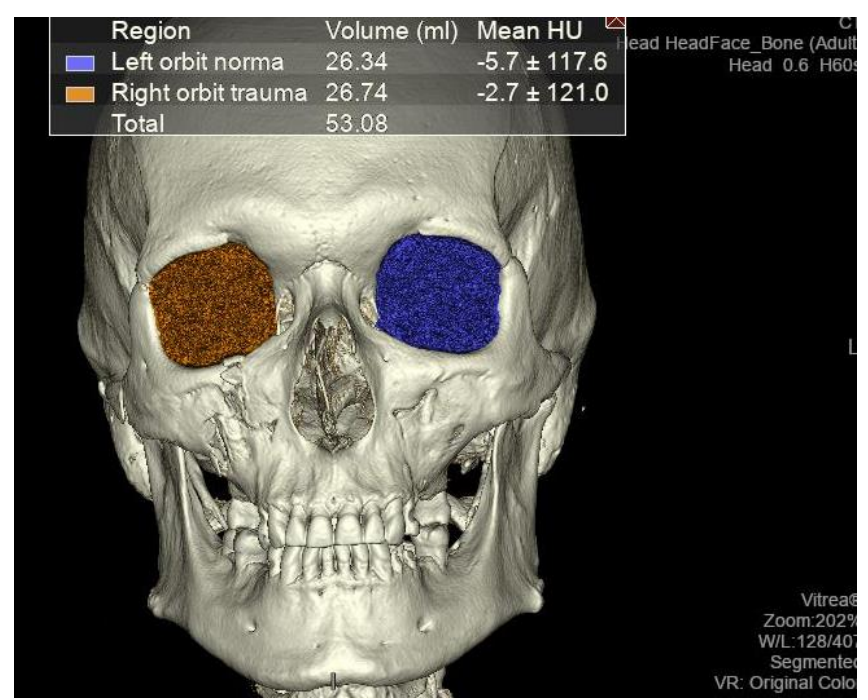

Рис. 5 в (Fig. 5 c)

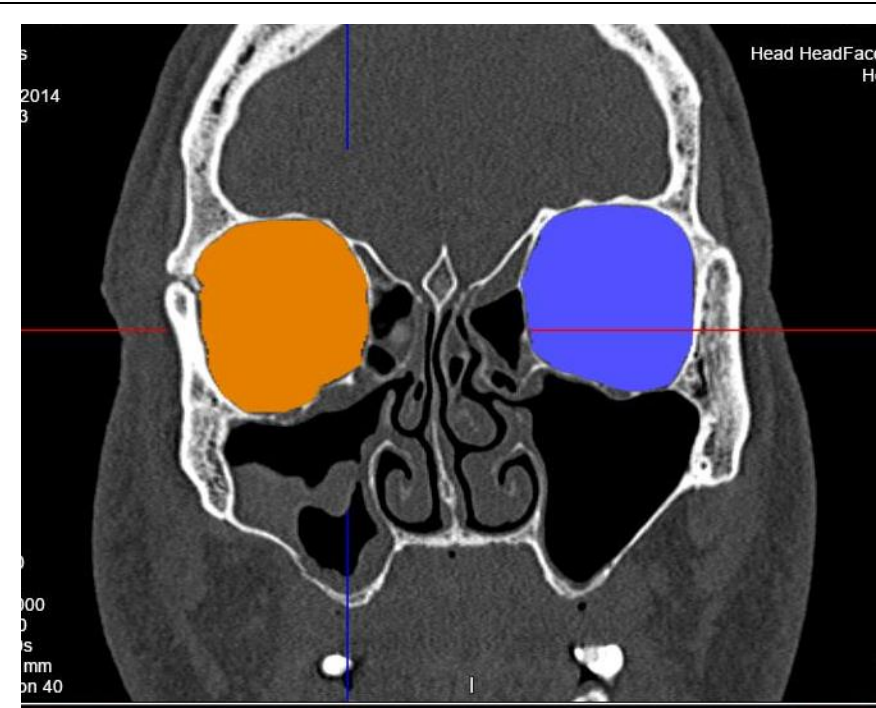

Pис. 5 б (Fig. 5 в)

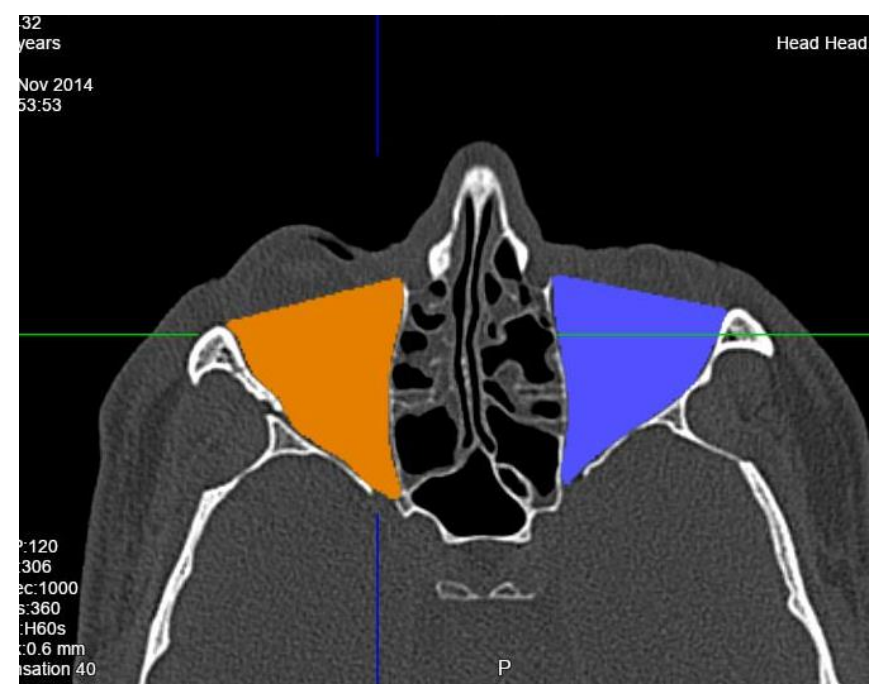

Puc. 5 r (Fig. 5 d)

Fig. 5. MSCT, midface, bone window.

Orbital volume assessment according to MSCT data in a patient within 48 hours after trauma using workstation. The difference between the affected and normal orbits according to the orbital volume assessment was $0,4 \mathrm{ml}$.

Рис. 5. МСКТ, среАняя зона Аица, костный режим. Измерение объёмов орбит после травмы на рабочей станции.

При подсчете объёмов поврежденной и здоровой орбит у данного пациента разница объёмов в течение 48 часов после травмы составима 0,4 мл. 


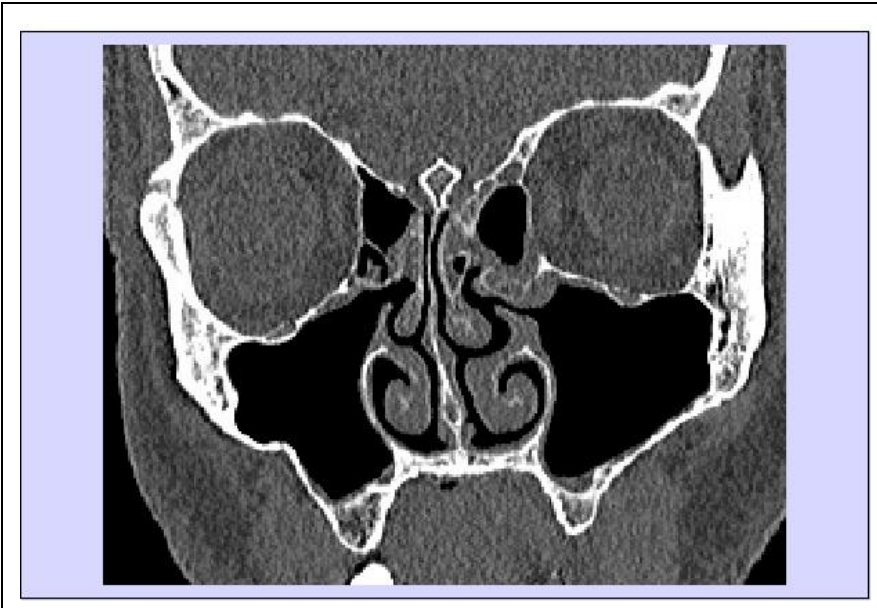

Рис. 6 a (Fig. 6 a)

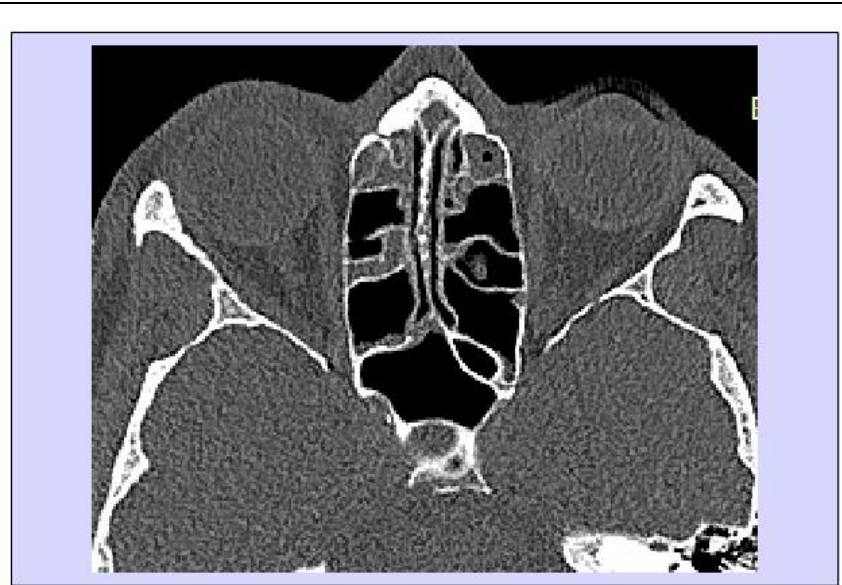

Puc. 6 б (Fig. 6 в)

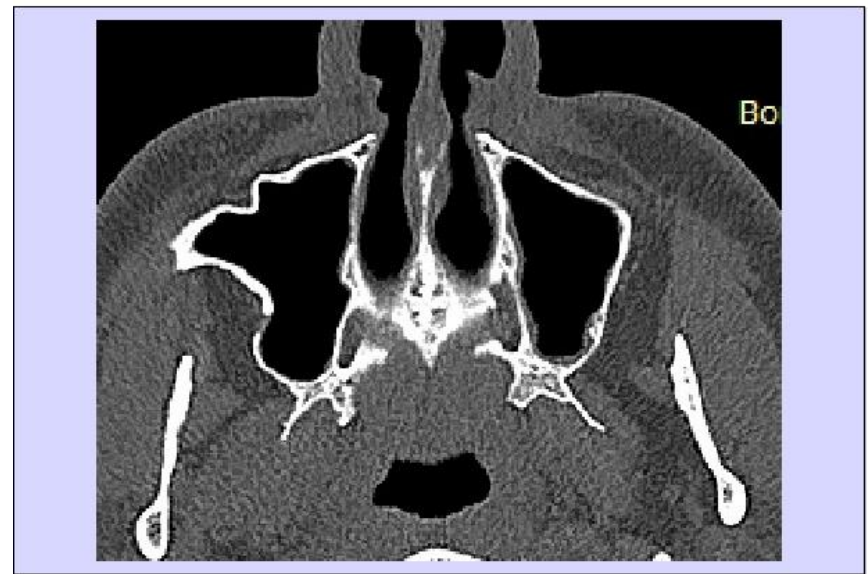

Pис. 6 в (Fig. 6 c)

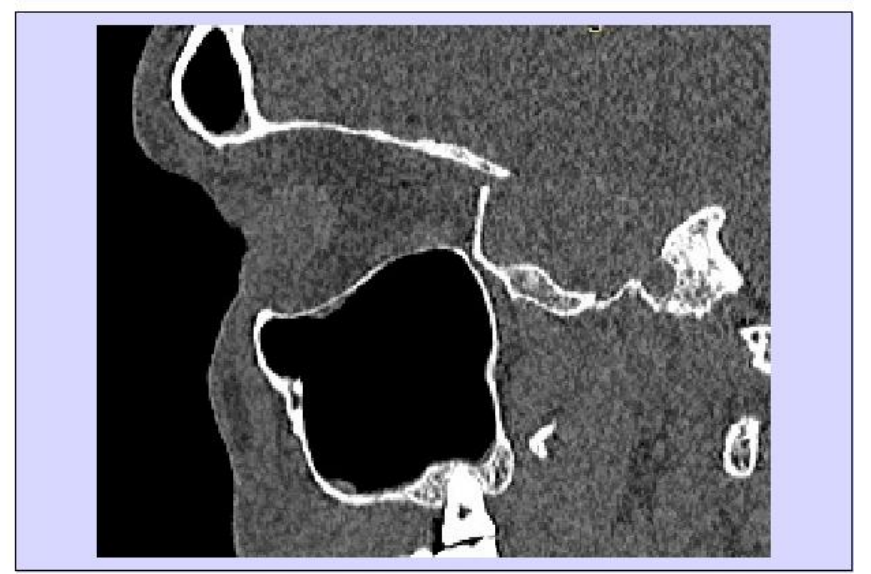

Puc. 6 г (Fig. 6 d)

Fig. 6. MSCT, midface, bone window, coronal (a), axial (b, c) and sagittal (d) reconstruction.

MSCT was performed in late posttraumatic period. There was reconstruction of orbital bony walls, maxillary sinus walls and zygomatic arch, as well as deformation of lateral maxillary sinus wall. There was no herniation of orbital content into the maxillary sinus.

Рис. 6. МСКТ, среАняя зона Аица, костный режим, корональная (а), аксиальная (б, в) и сагиттальная (г) реконструкции.

На полученных изображениях отмечается восстановцение костных стенок правой орбиты, а также восстановление стенок правого верхнечелюстного синуса и скуловой дуги, при этом визуализируется деформация матеральной стенки синуса. Пролабирования мягких тканей правой орбиты в верхнечелюстной синус не опредемяется. 


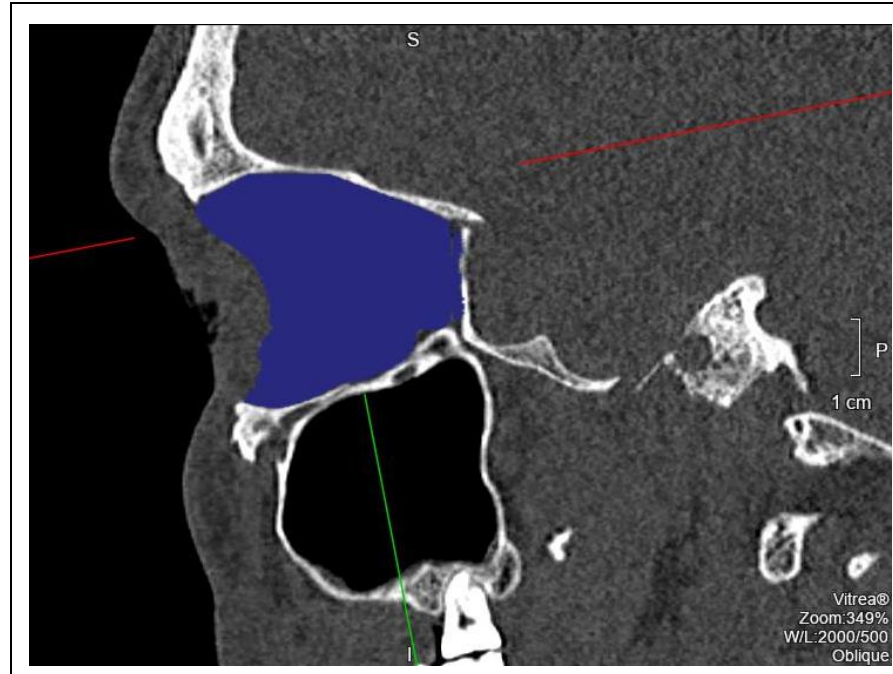

Рис. 7 a (Fig. 7 a)

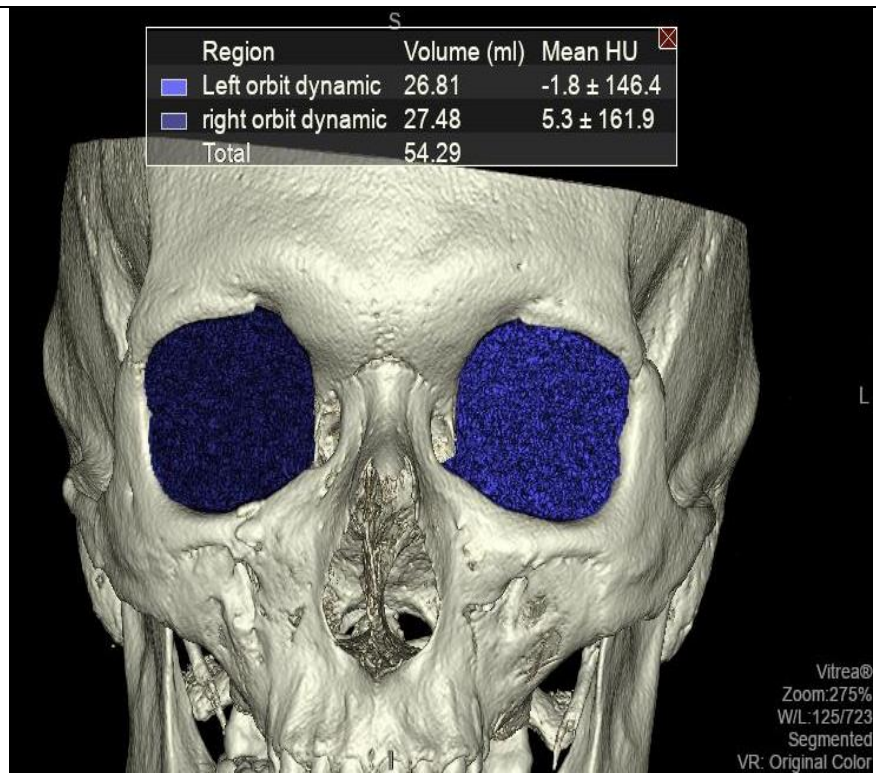

Рис. 7 в (Fig. 7 c)

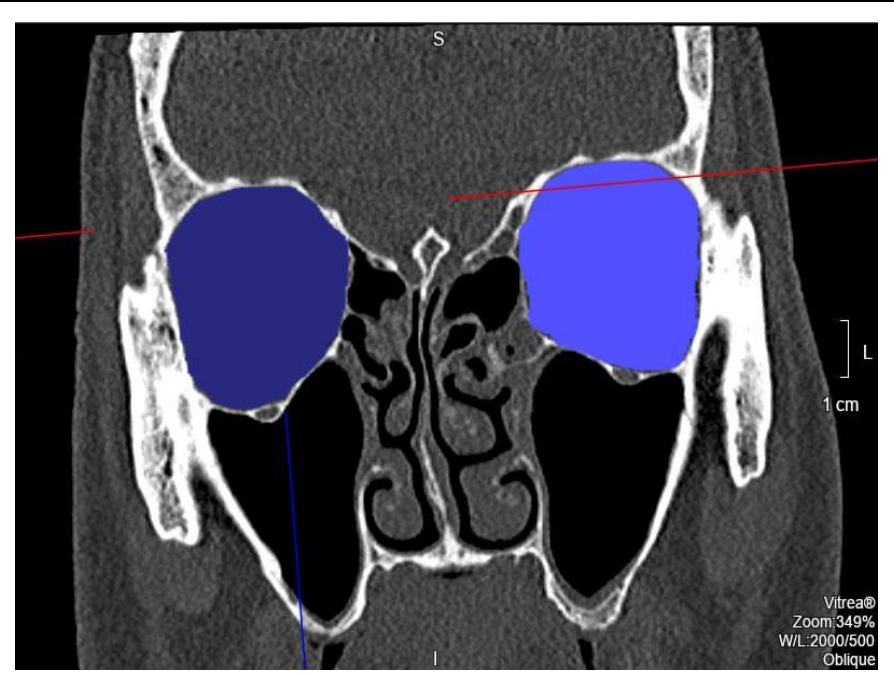

Pис. 7 б (Fig. 7 в)

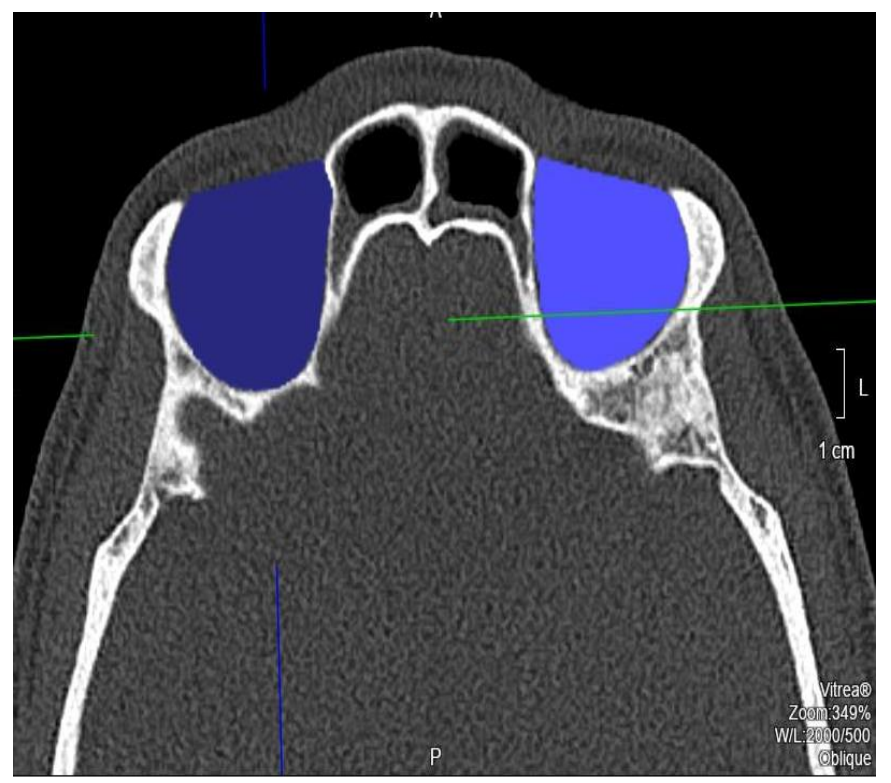

Pис. 7 г (Fig. 7 d)

Fig. 7. MSCT, midface, bone window.

Orbital volume assessment according to MSCT data in a patient within 48 hours after trauma using workstation. The difference between the affected and normal orbits in the late posttraumatic period was $0,67 \mathrm{ml}$.

Рис. 7. МСКТ, среАняя зона Аица, костный режим. Измерение объёмов орбит после травмы на рабочей станции.

Измерение объёмов орбит через 2 года после травмы. В позднем посттравматическом периоде разница объёмов травмированной и здоровой стороны составица 0,67 мл. 
The development of special postprocessing of the MSCT data gave the possibility to calculate pre-and postoperative orbital volume changes and present it in mathematical units $(\mathrm{ml})$ in 3D mode. This method allows prediction of globe prolapse which is one of the most severe posttraumatic complication and often results in persistent functional impairment of visual apparatus. As the result the additional information can be acquired about condition of bony orbital structures in order to identify the risk of postoperative enophthalmos.

\section{Cписок митературы:}

1. Дорожно-транспортные травмы. Информаиионный бюллетень $N^{\circ} 358$ (Октябрь 2015). Доступно по: http://www.who.int/mediacentre/factsheets/fs358/ru/

2. Дубровин М.С., Копеикий И.С., Полунин В.С. Медикосоииальная характеристика больных с повреждениями челюстно-лииевой области. Москва, Вестник Росздравнадзора, 2013. С. 46-48.

3. Караян А.С. Одномоментное устранение посттравма тических дефектов и деформаиий скуло-носо-глазничного комплекса. Докт.дисс. М., 2008. 190 с.

4. Серова Н.С. Аучевая диагностика сочетанных повреждений костей лииевого черепа и структур орбиты. Канд.дисс. M., 2006. 130 c.

5. Kubal W.S. Imaging of orbital trauma. RadioGraphics. 2008; 28: 1729-1739.

6. Whitehouse R.W., Batterbury M., Jackson A., Noble J.L. Prediction of enophthalmos by computed tomography after 'blow out' orbital fracture. Br J Ophthalmol. 1994; 78: 618-20.

7. Давыдов Д.В., Мевченко О.В., Михайлюков В.М Реконструктивная хирургия посттравматических дефектов и деформаиий глазницы с использованием интраопераиионной безрамной навигаиии. Вестник офтальмологии. 2014; 130 (2): 20-26.

8. Kolk A., Pautke C., Schott V., Ventrella E., Wiener E., Ploder O. Secondary post-traumatic enophthalmos: high-resolution magnetic resonance imaging compared with multislice computed tomography in postoperative orbital volume measurement. $J$ Oral Maxillofac Surg. 2007; 65: 1926-34.

9. Павлова О.Ю., Серова Н. С. Многосрезовая компьютерная томография в диагностике переломов глазнии. Вестник рентгенологии и радиологии. 2015; 3: 12-17.

10. Nastri A.L., Gurney B. Current concepts in midface fracture management. Curr Opin Otolaryngol Head Neck Surg. 2016; 24 (4): 368-75. doi: 10.1097/MOO.0000000000000267.

11. Клевно В. А. Эфррективные инструменты определения степени тяжести вреда, причиненного здоровью человека. Судебно-медииинская экспертиза. 2009; 1: 3-6.

12. Ауиевич Е.Э., Альхумиди К. Современные аспекты диагностики и лечения переломов орбиты. Вестник офтальмологии. 2013; 129 (б): 89-95.

13. Кобзева И.В. Особенности диагностики и планирования лечения пациентов с посттравматическими дефектами и деформациями средней зоны лииа. Автореферат канд.дисс. Москва, 2013. 23 c.

14. Костенко Д.И. Современные лучевые технологии диа-
It is our opinion that developed postprocessing of the MSCT data should be included in diagnostic protocol in every patient with orbital trauma within the preoperative planning, radiological dynamic control and assessment of surgical treatment.

Источник финансирования и конфАикт интересов.

Авторы данной статьи подтвердили отсутствие финансовой поддержки исследования и конфликта интересов, о которых необходимо сообщить. гностики и послеоперационного контроля у паииентов с деформаииями средней зоны лииа. Автореф. канд.дисс. М., 2017. 23 c.

15. Николаенко В.П., Астахов Ю.С. Орбитальные переломы: руководство для врачей. Спб., Эко-Вектор, 2012. 436 с.

16. Сангаева А.М., Серова Н.С., Выклюк М.В., Буланова Т.В. Аучевая диагностика травм глаза и структур орбить. Вестник рентгенологии и радиологии. 2007; 2: 60-64.

17. Furuta M. Measurement of Orbital Volume by Computed Tomography: Especially on the Growth of the Orbit. Jpn J Ophthalmol. 2001; 45: 600-606.

18. Ploder O., Klug C., Voracek M., Burggasser G., Czerny C. Evaluation of computer-based area and volume measurement from coronal computed tomography scans in isolated blowout fractures of the orbital floor. J Oral Maxillofac Surg. 2002; 60: 1267-72.

19. Павлова О.Ю., Серова Н.С. Протокол мультиспиральной компьютерной томографии в диагностике травм средней зоны лий. REJR. 2016; 6 (3): 91-96. DOI: 10.21569/2222-7415-2016-6-3-48-53.

20. Яиенко О.Ю., Тюрин И.Е. Рентгеноанатомия орбиты. Часть 1. Костная орбита и ее вершина. Вестник рентгенологии и радиологии. 2015; 3: 5-11.

21. Sidebottom A.J. The current management of midfacial trauma. Journal of oral biology and craniofacial research. 2013; 3: 1 20 e12 2.

22. Essig H., Dressel L., Rana M., Rana M., Kokemueller H., Ruecker M., Gellrich N. Precision of posttraumatic primary orbital reconstruction using individually bent titanium mesh with and without navigation: a retrospective study. Head \& Face Medicine. 2013; 9: 18.

23. Wagner M., Lichtenstein J., Winkelmann M., Shin H., Gellrich N., Essig H. Development and first clinical application of automated virtual reconstruction of unilateral midface defects. Journal of Cranio-Maxillo-Facial Surgery. 2015; 43: 1340e1347. 24. Raskin E.M., Millman A.L., Lubkin V., Rocca R.C., Lisman R.D., Maher E.A. Prediction of late enophthalmos by volumetric analysis of orbital fractures. Ophthal Plast Reconstr Surg. 1998; 14: 19-26.

25. Regensburg N.I., Kok P.H., Zonneveld F.W., Baldeschi L., Saeed P., Wiersinga W.M., Mourits M.P. A new and validated CT-based method for the calculation of orbital soft tissue volumes. Invest Ophthalmol Vis Sci. 2008; 49 (5): 1758-62. doi: 10.1167/iovs.07-1030. 


\section{RUSSIAN ELECTRONIC JOURNAL OF RADIOLOGY}

\section{References:}

1. Road traffic injuries. Fact sheet $N^{\circ} 358$. Updated October 2015. Available

at:

http://www.who.int/mediacentre/factsheets/fs358/ru/

2. Dubrovin M.S., Kopetskiy I.S., Polunin V.S. Medical and social characteristics of patients with maxillofacial injuries. Vestnik roszdravnadzora. 2013; 2: 46-48 (in Russian).

3. Karayan A.S. Single-step method of elimination of zygomaticoorbital posttraumatic defects and deformations. Doct. Diss. M., 2008. 190 p. (In Russian).

4. Serova N.S. Radiology of combined fractures of facial and orbital structures. Cand. Diss. O., 2006. 130 p. (in Russian).

5. Kubal W.S. Imaging of orbital trauma. RadioGraphics. 2008; 28: 1729-1739.

6. Whitehouse R.W., Batterbury M., Jackson A., Noble J.L. Pre diction of enophthalmos by computed tomography after 'blow out' orbital fracture. Br J Ophthalmol. 1994; 78: 618-20.

7. Davydov D.V., Levchenko O.V., Mikhailiukov V.M. Surgical reconstruction of posttraumatic defects and deformities of the orbit using frameless navigation. The Russian Annals of Ophthalmology. 2014; 130 (2): 20-26 (in Russian).

8. Kolk A., Pautke C., Schott V., Ventrella E., Wiener E., Ploder O. Secondary post-traumatic enophthalmos: high-resolution magnetic resonance imaging compared with multislice computed tomography in postoperative orbital volume measurement. $J$ Oral Maxillofac Surg. 2007; 65: 1926-34.

9. Pavlova O.Yu., Serova N.S. Multislice computed tomography in the diagnosis of orbital fractures. Journal of radiology. 2015; 3 : 12-17 (in Russian).

10. Nastri A.L., Gurney B. Current concepts in midface fracture management. Curr Opin Otolaryngol Head Neck Surg. 2016; 24 (4): 368-75. doi: 10.1097/MOO.0000000000000267.

11.Klevno V.A. Effective instruments of definition of severity harm to health. Forensic Medical Expertise. 2009; 1: 3-6 (in Russian).

12. Lutsevic E.Ye., Al'khumidi K. Modern aspects of diagnostic and treatment of orbital fractures. The Russian Annals of Ophthalmology. 2013; 129 (6): 89-95 (in Russian).

13. Kobzeva I.V. The features of diagnostics and treatment planning with midface posttraumatic defects and deformations. Cand.Diss. M., 2013. 23 p. (in Russian).

14. Kostenko D.I. Modern radiology technologies in diagnostics and postoperative control in patients with midface deformations.
Cand.Diss. M., 2017. 23 p. (in Russian). 15. Nikolaenko V.P., Astakhov Yu.S. Orbital fractures: guidance for doctors. Spb., Eco-Vector, 2012. 436 p. (in Russian). 16. Sangaeva L.M., Serova N.S., Vykluk M.V., Bulanova T.V. Radiology of globe and orbital trauma. Journal of radiology. 2007; 2: 60-64 (in Russian).

17. Furuta M. Measurement of Orbital Volume by Computed Tomography: Especially on the Growth of the Orbit. Jpn J Ophthalmol. 2001; 45: 600-606.

18. Ploder O., Klug C., Voracek M., Burggasser G., Czerny C. Evaluation of computer-based area and volume measurement from coronal computed tomography scans in isolated blowout fractures of the orbital floor. J Oral Maxillofac Surg. 2002; 60: 1267-72.

19. Pavlova O.Yu, Serova N.S. MSCT protocol in midface trauma diagnostics. REJR. 2016; 6 (3): 48-53. DOI:10.21569/22227415-2016-6-3-48-53 (in Russian).

20. Yatsenko O.Y., Tyurin I.E. Orbital radiographic anatomy. Part 1. The osseous orbit and its apex. Journal of radiology. 2015; 3: 5-11. DOI:10.20862/0042-4676-2015-0-3-5-11(in Russian).

21. Sidebottom A.J. The current management of midfacial trauma. Journal of oral biology and craniofacial research. 2013; 3: 1 20 e1 22.

22. Essig H., Dressel L., Rana M., Rana M., Kokemueller H., Ruecker M., Gellrich N. Precision of posttraumatic primary orbital reconstruction using individually bent titanium mesh with and without navigation: a retrospective study. Head \& Face Medicine. 2013; 9: 18.

23. Wagner M., Lichtenstein J., Winkelmann M., Shin H., Gellrich N., Essig H. Development and first clinical application of automated virtual reconstruction of unilateral midface defects. Journal of Cranio-Maxillo-Facial Surgery. 2015; 43: 1340e1347.

24. Raskin E.M., Millman A.L., Lubkin V., Rocca R.C., Lisman R.D., Maher E.A. Prediction of late enophthalmos by volumetric analysis of orbital fractures. Ophthal Plast Reconstr Surg. 1998; 14: 19-26.

25. Regensburg N.I., Kok P.H., Zonneveld F.W., Baldeschi L., Saeed P., Wiersinga W.M., Mourits M.P. A new and validated $C T$-based method for the calculation of orbital soft tissue volumes. Invest Ophthalmol Vis Sci. 2008; 49 (5): 1758-62. doi 10.1167/iovs.07-1030 